\title{
Quem ama bloqueia: a publicidade-entretenimento no ciberespaço
}

Pablo Moreno Fernandes Viana

Mestre em Comunicação e professor pela PUC-Minas.

\section{RESUMO}

Este artigo apresenta uma análise de um website utilizado pela operadora de telefonia $O i$ na campanha pelo desbloqueio de celulares. Os dois websites que integraram a campanha ("Bloqueio não" e "Quem ama bloqueia") caracterizam-se por utilizar gêneros específicos da publicidade, aqui categorizados como publicidade comparativa e publicidade-entretenimento. A análise busca investigar os valores que a publicidade-entretenimento é capaz de agregar à marca e as formas de produção de sentido de sua mensagem.

PALAVRAS-CHAVE: publicidade, entretenimento, semiótica.

\section{ABSTRACT}

This article presents an analysis of a website used by the telephonic operator $O i$ in a campaign by cell phones unblocking. The two websites that joined the campaign ("No Blockade" and "Who Loves Blocks") are characterized by use two specifics advertising genders, here categorized as comparative advertising and advertainment. The purpose is to investigate the values added by advertainment to the telephonic operator's identity and ways of meaning from its message.

KEYWORDS: advertising, entertainment, semiotics.

Este artigo propõe analisar a ação publicitária realizada pela operadora de telefonia móvel Oi, “Quem ama bloqueia". Em crítica ao bloqueio de aparelhos celulares com chips de outras operadoras, a campanha, veiculada em 2007, obteve grande visibilidade na sociedade.

Propõe-se analisar a estratégia de hibridação da publicidade com o entretenimento em determinado momento da campanha. O website "Quem ama bloqueia" será analisado sob a perspectiva da publicidadeentretenimento. Ele não se caracteriza exclusivamente como publicidade por não apresentar os argumentos típicos desse gênero midiático, mas por apropriar-se dele como recurso de ironia.

\section{Bloqueio não: publicidade comparativa?}

A $O i$ vislumbrava, desde 2005, não comercializar mais aparelhos celulares, apenas chips. Porém, o que se observava no mercado brasileiro de telefonia celular até então é que as operadoras (inclusive a própria $\mathrm{Oi}$ ) vendiam os aparelhos bloqueados ao funcionamento com chips das concorrentes. Antes de parar de vender aparelhos, seria necessário, portanto, habituar os consumidores a exigirem, no ato da compra, aparelhos desbloqueados.

Para tanto, a operadora lançou em 2007 a campanha "Bloqueio não", baseada numa estratégia do marketing de guerrilha conhecida como astroturfing. Nessa estratégia, as ações publicitárias são desenvolvidas 
como se fossem iniciativas populares de mobilização social. A campanha trabalhava com anúncios de TV e mídia impressa, utilizando uma linguagem agressiva, mobilizando a luta contra o bloqueio dos celulares.

Essas peças convidavam o sujeito a visitar o website "Bloqueio não" (www.bloqueionao.com.br). O website tinha como objetivo principal arrecadar assinaturas para um abaixo-assinado que seria entregue à Agência Nacional de Telecomunicações (Anatel), solicitando a criação de uma regra que proibisse o bloqueio de aparelhos.

No início da campanha, alguns blogs foram remunerados para inserir o selo com a marca da campanha em seus templates. A partir de então, a campanha ganhou adesão popular e outros blogs e websites aplicaram o selo espontaneamente, gerando um número significativo de mídia espontânea, o que sinaliza para o sucesso da ação de astroturfing.

$\mathrm{O}$ website apresentava ataques diretos às operadoras concorrentes por meio de depoimentos de internautas, artistas e notícias extraídas da imprensa. Nos primeiros quatro meses em que permaneceu no ar, mais de 1 milhão de assinaturas foram colhidas. Porém, em determinado momento, o "Bloqueio não" foi retirado do ar em função de liminar judicial obtida pela operadora Claro, concorrente da Oi. Isso se deu em função de denúncia feita pela $O i$ a respeito de uma oferta promocional da Claro (1).

A ação da $O i$ de denunciar a oferta da Claro vinculando promoções ao "Bloqueio" poderia ser categorizada como publicidade comparativa, já que aponta e menciona o nome da operadora que pratica o bloqueio, num espaço que é da $O i$ (o website da campanha). A publicidade comparativa faz menção às marcas dos produtos rivais, exibindo-as durante a mensagem publicitária, na intenção de apontar a superioridade da marca anunciante.

A atividade publicitária no Brasil é fiscalizada pelo Conselho Nacional de Auto-Regulamentação da Atividade Publicitária (Conar). As campanhas devem atender exigências estabelecidas no código elaborado pelo Conselho e, caso alguma campanha em veiculação infrinja alguma das suas regras, ela é investigada sob o risco de sair do ar com sanções para o anunciante.

No Código Brasileiro de Auto-Regulamentação publicitária há uma seção que aborda especificamente a Propaganda Comparativa, recomendando conduta às agências sobre a utilização e a criação desse tipo de publicidade.

Sob os aspectos da legislação brasileira, Barroso (2003) apresenta as seguintes definições legais acerca da propaganda comparativa:

a lei federal $n^{\circ} 4.680 / 65$, que dispôs sobre o exercício da profissão de publicitário e de agenciador de propaganda [...] estabeleceu, no seu art. 17, que "a atividade publicitária será regida pelos princípios e normas" do código já aludido. Já o decreto $n^{0} 57.690 / 66$, que aprovou o regulamento para execução da mencionada lei, prescreveu, no seu art. 17, ao tratar da ética profissional: 
Art. 17. A agência de propaganda, o veículo de divulgação e o publicitário em geral, sem prejuízo de outros deveres e proibições previstos neste regulamento, ficam sujeitos, no que couber, aos seguintes preceitos, genericamente ditados pelo Código de Ética dos Profissionais da Propaganda a que se refere 0 art. 17, da lei 4.680, de 18 de junho de 1965 :

I - Não é permitido:

$[\ldots]$

d) difamar concorrentes e depreciar seus méritos técnicos;

e) atribuir defeitos ou falhas a mercadorias, produtos ou serviços concorrentes (BARROSO, 2003: 116).

Outras esferas legais também abordam aspectos sobre a legislação da publicidade, como o Código de Defesa do Consumidor. O Código trata de questões acerca da propaganda enganosa, da propaganda abusiva, mas não traz informação precisa acerca da propaganda comparativa. O que mais se aproxima dessa definição é o artigo 36, que aborda a clareza da mensagem publicitária. "A publicidade deve ser veiculada de tal forma que o consumidor, fácil e imediatamente, a identifique como tal.” (BRASIL, 1990: 9).

Em outros países utiliza-se, frequentemente, a exibição das marcas de concorrentes em anúncios nos quais são realizados testes comparativos de produtos. A legislação brasileira não proíbe a veiculação de campanhas publicitárias comparativas, porém é muito rara a veiculação de campanhas assim. Observa-se, nos raros casos em que campanhas comparativas são veiculadas no país, que o rigor no cumprimento às leis é grande, o que resulta, muitas vezes, na determinação de que a mesma seja retirada do ar.

A determinação para a retirada do website "Bloqueio não" do ar não se deu em função da legislação acerca da propaganda comparativa. A justificativa para a concessão da liminar foi embasada no argumento de que a operadora poderia bloquear o aparelho do seu cliente como forma de fidelização, em função do desconto concedido na aquisição do aparelho. A operadora $O i$ aproveitou-se da situação e publicou, no lugar do website, um aviso de que a operadora Claro havia recorrido na justiça contra a pretensa liberdade dos clientes sobre a escolha de operadora.

A campanha trabalha com a mistura de gêneros midiáticos diversos. A linguagem trabalhada no website era semelhante à do jornalismo. Os depoimentos em primeira pessoa, as matérias veiculadas na imprensa sobre o desbloqueio de celulares e o tom de denúncia utilizado nos textos reforçam tal hibridação de gênero. Nas peças de mídia impressa, o tom de sobriedade era mais marcante, utilizando-se cores mais escuras e o contraste entre preto, branco e vermelho.

Com a retirada do ar do "Bloqueio não", os esforços da campanha foram direcionados ao website "Quem ama bloqueia", de linguagem mais sutil e sem ataques diretos à concorrência. A campanha já havia atingido seu objetivo inicial, a população já estava mobilizada, a música-tema já havia caído no gosto popular e o abaixo-assinado pressionando o governo a criar uma lei que proibisse o bloqueio já havia conseguido um número significativo de assinaturas. 
Paralelamente à briga judicial entre Oi e Claro pela retirada do website "Bloqueio não" do ar, em outubro de 2007, dando continuidade à campanha contra o bloqueio dos aparelhos, entrou no ar o website "Quem ama bloqueia" (www.quemamabloqueia.com.br). Ele foi criado a partir do sucesso do jingle da campanha, no qual personagens vestidos de amarelo com a identificação "Operadora” no peito algemavam pessoas (em menção ao bloqueio de aparelhos) e cantavam o refrão "Quem ama bloqueia”.

Ao contrário do "Bloqueio não", que possuía assinatura institucional da Oi, o "Quem ama bloqueia" não possuía o logotipo da operadora em suas páginas. Pelo contrário, todo o discurso do site era apresentado como fala das operadoras que bloqueiam seus aparelhos. Porém, o texto era construído com bastante ironia, permitindo ao receptor identificar aquela mensagem como uma piada contra as operadoras que praticavam o bloqueio. O texto abaixo, extraído do primeiro link comprova esta afirmação:

A gente é a favor do bloqueio de celular. Porque bloquear é uma prova de amor. Se você comprou um celular da nossa operadora, você não é só um cliente. Você é nosso. O celular não é seu. É nosso. Sabe por quê? Porque a gente te ama. E quem ama, bloqueia!

O que se observa no website "Quem ama bloqueia" é um discurso mais próximo da lógica do entretenimento do que da publicidade observada em outras mídias, porém bastante comum no ambiente virtual. Embora ele integre ações promocionais da $O i$, como parte da campanha publicitária, não se apresenta para seu receptor como uma ação publicitária tradicional. Pelo contrário, aparece como um espaço no qual o receptor tem acesso a conteúdos cujo objetivo inicial é proporcionar o entretenimento.

Essa publicidade embasada no entretenimento é denominada por Longo (2007) advertainment (mistura do termo advertising com entertainment). Ela ganha status de mídia quando independe da existência de um veículo para a sua inserção, podendo existir no ciberespaço provendo conteúdo específico ao seu público, que o acessará por conta própria e quando bem entender, subvertendo a lógica tradicional da publicidade nos meios de comunicação.

A página inicial traz os personagens da campanha em cima de um palco com microfones na mão. $\mathrm{O}$ uso de personagens é muito comum na publicidade e visa facilitar a assimilação da mensagem publicitária e o estabelecimento de laços afetivos dos sujeitos com a ação. O personagem busca estabelecer um distanciamento da marca $O i$ com o website, já que o discurso é apresentado como fala das operadoras concorrentes, e não pela Oi.

Analisando-se os personagens do "Quem ama bloqueia", percebe-se que eles facilitam o estabelecimento da relação texto-imagem, possibilitando a identificação do emissor da mensagem (as operadoras que bloqueiam os aparelhos), ao mesmo tempo em que cria a conexão entre a campanha "Bloqueio não" e o website. 
O website divulgava, a princípio, o concurso "Algema dourada" (novamente o recurso da ironia para referir-se às operadoras que fazem uso do aparelho celular como forma de aprisionar seus clientes aos seus serviços). No concurso, os internautas poderiam enviar vídeos caseiros produzidos utilizando a música-tema da campanha. A interface do website é semelhante à do site de vídeos Youtube e os visitantes podiam comentar e ainda votar no vídeo que quisessem como vencedor do concurso. O vencedor do concurso foi divulgado em 26 de janeiro de 2008 e o prêmio para o primeiro lugar foi um aparelho celular desbloqueado, habilitado na operadora $\mathrm{Oi}$.

Observa-se o uso da função apelativa da linguagem ao longo das páginas do website. Essa função da linguagem é peculiar ao discurso da publicidade. $\mathrm{O}$ uso de vocativos, frases curtas e da oralidade no discurso também é índice da linguagem publicitária. A função apelativa aparece como índice de ironia, uma vez que o texto apresenta o bloqueio como uma forma de amor, algo positivo, e afirma que o aparelho celular comprado (e pago pelo sujeito) não é seu, e sim da operadora.

A intenção não é esconder o tom de ironia à concorrência, uma vez que no rodapé de todas as páginas está o seguinte texto: "Se bloqueio de celular fosse bom, as operadoras falariam deste jeito. Liberte o seu celular. Participe do abaixo-assinado contra o bloqueio". Nessa área, o internauta é direcionado, mediante clique, para o "Bloqueio não", assinado institucionalmente pela $\mathrm{Oi}$.

Observa-se, do ponto de vista semiótico, a apresentação inicial do emissor como rema, signo de mensagem opaca, incapaz de oferecer ao seu leitor todas as informações necessárias à sua interpretação:

Um signo que, para seu Interpretante, é um Signo de Possibilidade qualitativa, ou seja, é entendido como representando esta e aquela espécie de objeto possível. Todo Rema propiciará, talvez, alguma informação, mas não interpretado nesse sentido (PEIRCE, CP 2.250).

A mensagem surge sobre a estrutura de signo remático porque oculta os índices que deveriam garantir o entendimento de quem é o emissor para depois, numa leitura do conjunto, revelar-se como campanha publicitária da operadora $\mathrm{Oi}$. Nesse caso, insere-se, propositalmente, uma carga de ruído que irá contribuir para o pacto semiótico entre o leitor e o conteúdo da mensagem. Esse ruído desaparece, à medida que a mensagem se descortina, por meio de signos dicentes. Peirce define o signo dicente como

um signo que, para seu interpretante, é um Signo de existência real. Portanto, não pode ser um Ícone o qual não dá base para interpretá-lo como sendo algo que envolve, como parte dele um Rema para descrever o fato que é interpretado como sendo por ela indicado (PEIRCE, CP 2.251).

A partir desses signos o sujeito será capaz de identificar a mensagem, por meio de um raciocínio abdutivo que lança hipóteses sobre o pacto semiótico que o sujeito irá estabelecer com o website. Conforme 
novas informações são acrescentadas à mensagem, o visitante identifica a real intenção da mensagem, até desvendar os signos apresentados.

O concurso "Algema dourada" e os vídeos funcionam como o principal elemento capaz de proporcionar ao internauta a imersão e a permanência, e estimulam o retorno ao website. Em virtude da pouca quantidade de links, em poucos minutos é possível navegar por todas as páginas. Porém, para assistir a todos os vídeos, leva-se uma quantidade considerável de tempo, em função do volume de participantes do concurso.

A proposta de entretenimento é reafirmada em diversos momentos, como nos vídeos postados para o concurso e em outros links, como "Ensaio". Sua existência justificava-se principalmente nos primeiros momentos em que o website esteve disponível para acesso, uma vez que não havia volume significativo de conteúdo em vídeo para manter o internauta naquele espaço.

Convidando o internauta à interação, o texto da página propõe: “Aprenda agora, passo a passo, a coreografia que conquistou o Brasil". Temos novamente o texto publicitário valendo-se da ironia, pelo uso do exagero (conquistou o Brasil) típico da linguagem da publicidade. Uma animação mostra os movimentos da coreografia conforme o internauta desloca o mouse sobre as imagens, apresentando os passos a cada verso da canção. A coreografia é simples e o riso é proporcionado, também, pela expressão irônica do personagem que a demonstra.

Mais abaixo, um link convida novamente o sujeito a interagir com o website, aumentando sua experiência imersiva. O texto "Quer aprender a tocar? Clique aqui para baixar as cifras e a partitura da música" no final da página direciona o internauta a uma página com a cifra da canção, outro recurso que busca manter o sujeito entretido naquele espaço. Outra característica que se observa é a tentativa de tornar o jingle popular entre os sujeitos, que poderão tocá-la em qualquer contexto, rompendo as barreiras do universo da publicidade para além da mídia.

No link "Karaokê", o internauta pode cantar o tema da campanha. Por meio de um vídeo produzido exclusivamente para esse link, o personagem da operadora aparece como um maestro na tela, a canção é executada, apenas por meio de instrumentos, e a letra é indicada, realçando-se de amarelo de acordo com o andamento da canção. É possível, ainda, cantar-se o jingle em inglês, espanhol e italiano. Percebe-se mais um índice de ironia às operadoras concorrentes, visto que a Claro tem capital chileno em sua composição, e a Tim, italiano. Neste caso, após o clique, o vídeo apresenta a letra no idioma correspondente selecionado.

Todo esse conteúdo, embora tenha o caráter de publicidade, atua na intenção de propiciar o entretenimento. Luhmann (2005: 94) define que a lógica do entretenimento nos meios de comunicação de massa se aproxima da lógica dos jogos, apesar de não presumir algum comportamento complementar dos parceiros envolvidos ou de regras combinadas anteriormente.

O karaokê e a cifra reforçam a proposta do entretenimento midiático, pois permite que o tema publicitário seja memorizado e cantado por outras pessoas. Além disso, há o link para acessar a cifra da música 
para tocá-la com instrumentos musicais, e, no fim da página, o link para enviar o conteúdo da página a amigos - que representa a possibilidade da disseminação do conteúdo pelos internautas, conhecida como marketing viral, mais uma estratégia do marketing de guerrilha. Todos esses recursos oferecem outras possibilidades de imersão ao sujeito no espaço, buscando aumentar seu tempo de permanência no website.

Nos jogos, os participantes são levados a uma realidade independente, na qual eles podem presenciar o início e o fim. O entretenimento faz surgir uma realidade ficcional exclusiva a ele, delimitada por uma seqüência de comportamentos aceitos dentro daquele espaço, por meio da experiência de imersão. Essa realidade, embora gerada para aquele ambiente, não é um falseamento, e sim um facilitador à entrada dos receptores naquele contexto.

Esse mundo da imaginação não necessita de nenhuma regra especial, pois não precisa coordenar nenhum comportamento social do observador. Em vez disso, ele precisa de informação. E exatamente isso permite aos meios de comunicação, com base em seu código informação/não informação, construir um setor de entretenimento na programação (LUHMANN, 2005: 95-96).

O entretenimento midiático não presume do receptor um envolvimento com a mensagem ou a obrigação de resposta aos estímulos que recebe. O sujeito pode atuar naquela realidade apenas como espectador, se essa for a sua vontade. Luhmann afirma que:

Entretenimento significa não procurar nem encontrar nenhum motivo para responder à comunicação com comunicação. Em vez disso, o observador pode concentrar-se na vivência e nos motivos das pessoas apresentados no texto e nesse caso praticar a observação de segunda ordem. E, como se trata "apenas" de entretenimento, a questão da autenticidade não se coloca, como ocorreria no caso de uma obra de arte (LUHMANN, 2005: 102).

A mensagem apropria-se da estrutura de outros produtos midiáticos. Essa apropriação, observada quando uma mídia agrega outra mídia em sua estrutura, é conceituada por Bolter e Gruisin (2000) como remediation. Tal teoria apresenta dois conceitos relevantes para a análise do website: a immediacy e a hypermediacy.

A immediacy diz respeito à transparência da mediação, numa tentativa do meio de se apagar da experiência do sujeito, proporcionando sua imersão naquele ambiente com naturalidade. É por meio dela que a publicidade propõe ao receptor sua leitura sob a ordem do entretenimento. A immediacy propõe a transparência e, no caso da publicidade, apagam-se as características que permitiriam ao receptor reconhecer a mensagem como tal.

A hypermediacy trata justamente da consciência a respeito daquela mediação que, na tentativa de se tornar extremamente transparente, atrai o olhar do receptor para a sua opacidade. Sobre a hypermediacy, Bolter e Gruisin afirmam que: 
A lógica da hypermediacy multiplica os signos da mediação e, nesse caminho, tenta reproduzir a riqueza sensorial da experiência humana. Por outro lado, a hypermediacy pode operar ainda em um meio exclusivo e aparentemente unificado, particularmente quando a ilusão de representação realista é de alguma forma esticada ou, ao mesmo tempo rompida (BOLTER; GRUISIN, 2000: 34) (2).

$\mathrm{Na}$ publicidade percebe-se o uso da hypermediacy, uma vez que seu discurso tenta claramente convencer o receptor sobre as vantagens do produto. Esse discurso delimitado pela duração do anúncio e pela sua presença numa faixa de programação reservada apenas às mensagens publicitárias - o intervalo comercial - não proporciona uma experiência autêntica de imersão. Na publicidade-entretenimento, a hypermediacy surge após a imersão naquele espaço, demonstrando a opacidade da mensagem.

No website "Quem ama bloqueia" o que se observa é a tentativa de envolver o receptor naquela experiência por meio da imersão e do entretenimento. A mensagem apresenta uma transparência carregada de ruído, que chama atenção para a sua opacidade. Porém, recursos como o karaokê e a coreografia vão ao encontro da idéia de hypermediacy, pois a mediação mostra as suas barreiras, propondo ao sujeito que participe (seja dançando, cantando ou tocando) do universo midiático da publicidade, levando sua mensagem para além dos limites da mídia.

\section{Considerações finais}

Embora não apresente a marca da empresa anunciante, o website "Quem ama bloqueia" é capaz de agregar valores afetivos e simbólicos para a $\mathrm{Oi}$ ao propor o entretenimento e a imersão. Por utilizar-se da ironia à linguagem publicitária e às concorrentes, o processo de interpretação sobre quem é o assinante da campanha fica por conta do sujeito, porém todos os índices conduzem a uma única resposta.

$\mathrm{O}$ recurso da ironia revela ao internauta a publicidade da $O i$ numa estrutura diferente à da publicidade tradicional, ao apontar os pontos negativos da concorrência (vender aparelhos bloqueados) sem mencionar os seus nomes. Desse modo, a concorrência não pode usar de aspectos judiciais para determinar a retirada da ação do ar. As mensagens subjetivas sobre as outras operadoras, o discurso colocado "na boca" da concorrência e os índices sobre quem é o responsável pela mensagem tornam a mensagem publicitária sutil e ao mesmo tempo divertida, o que gera simpatia pela ação frente a seu público.

Os textos, as imagens e texturas utilizadas com apelo e unidade conceitual típicos da publicidade demonstram o uso das técnicas da propaganda, porém carregadas de ironia. Ao propor o riso, ironizando a linguagem da publicidade, o que se percebe é que ela busca estabelecer com seu receptor pacto semiótico no qual ele seja capaz de identificar o referencial simbólico da publicidade, mas também seu uso com a intenção de proporcionar o riso. Ela subverte os valores da publicidade tradicional, ao apresentar o bloqueio como algo positivo, porém afirmado pela concorrência. $\mathrm{O}$ website consegue estabelecer um comparativo entre a $O i$ e a concorrência e deixa as informações ao seu receptor sobre aquilo de que se trata. Porém, pelo fato de não expor 
a marca das concorrentes, não cria problemas do ponto de vista legal para a operadora. O receptor fica nesse constante jogo acerca da mensagem que ora afirma, ora dá pistas que refutam quem é o emissor da mensagem.

Nesse caso, o raciocínio abdutivo está no uso da linguagem da publicidade e no descrédito dado a essa linguagem pela ironia. Também pode ser identificado na não-assinatura da mensagem pela $O i$ e nos textos em primeira pessoa. Embora o sujeito saiba quem é o responsável pela ação, o site "coloca" os textos no discurso da concorrência, proporcionando novamente essa modificação no pacto de leitura, que também tem como objetivo proporcionar o riso.

A quantidade de assinaturas obtida no abaixo-assinado contra o bloqueio de aparelhos, bem como a criação da regra que obriga as operadoras a venderem aparelhos desbloqueados, a grande quantidade de vídeos publicados no website para o concurso "Algema dourada” e, mais ainda, a popularização do refrão "Quem ama bloqueia" indicam o êxito da ação. Observa-se ainda a grande participação dos meios de comunicação na campanha publicitária. Porém, mais representativa é a adesão dos sujeitos do ciberespaço na campanha. Diversos blogs inseriram o selo "Bloqueio não" em suas páginas e a campanha foi notícia em diversos jornais e revistas especializadas.

O êxito da campanha sinaliza para uma tendência à participação cada vez maior do ciberespaço nas campanhas publicitárias e no uso de estratégias que venham envolver os sujeitos participantes dos ambientes virtuais. Ao contrário dos meios de comunicação de massa, no qual o espaço de visibilidade é quantificado e vendido, na web a grande segmentação e a existência de diversos pontos fortes na rede comunicacional exige que as estratégias sejam focadas nesses nós de relevância, que devem ser mobilizados a participar de uma campanha para que ela obtenha visibilidade. Ao mesmo tempo, a visibilidade obtida na rede retorna sob o formato de mídia espontânea em veículos de comunicação, garantindo ainda mais visibilidade à campanha.

\section{Notas}

(1) No caso, o cliente que adquirisse um aparelho bloqueado na Operadora (Claro) teria direito a um desconto na aquisição do mesmo.

(2) Do original em inglês: "The logic of hypermediacy multiplies the signs of mediation and in this way tries to reproduce the rich sensorium of human experience. On the other hand, hypermediacy can operate even in a single and apparently unified medium, particularly when the illusion of realistic representation is somehow stretched or altogether ruptured" (BOLTER e GRUISIN, 2000: 34).

\section{REFERÊNCIAS}

BARROSO, Felipe dos Reis. "Propaganda comparativa à luz do direito brasileiro". In: Revista Humanidades, n.2. Fortaleza, 2003.

BOLTER, Jay David e GRUISIN, Richard. Remediation: understanding new media. Massachussets: The MIT Press, 2000. 
Brasil. Código de Defesa do Consumidor. Rio de Janeiro, 2008.

CARVALHO, Nelly. Publicidade: a linguagem da sedução. São Paulo: Ática, 2000.

CASAQUI, Vander. "História da propaganda brasileira: dos fatos à linguagem". In: PEREZ, Clotilde e BARBOSA, Ivan Santo (orgs.) Hiperpublicidade: fundamentos e interfaces. V.1. São Paulo: Thomsom Learning, 2007.

DEBORD, Guy. A sociedade do espetáculo. Rio de Janeiro: Contraponto, 1997.

DURIGAN, P. L. Publicidade comparativa: informação persuasiva e concorrência. Curitiba, 2007. Dissertação de mestrado. Faculdades Integradas Curitiba. Disponível em: www.apriori.com.br/artigos/publicidadecomparativa.pdf

ELIAS, Herlander. "Brand New World: o novo mundo da antipublicidade". In: Jornada de Publicidade e Comunicação. N.2, 2006, Covilhã. Disponível em: http://www.bocc.ubi.pt

FAUSTO NETO, Antônio. "Contratos de leitura: entre regulações e deslocamento". In: XXX Congresso Brasileiro de Ciências da Comunicação. Unisanta/Unisantos/Unimonte. Anais Intercom 2007. Disponível em: http://www.intercom.org.br.

HAAS, Claude Raymond. A publicidade: teoria, técnica e prática. Lisboa: Pórtico, s/d.

HEYMER, Mourylise. Easyvertising: website de apoio à criação de publicidade para a web. Dissertação de mestrado. Faculdade de Engenharia da Universidade do Porto. Portugal, 2005.

LIPOVETSKY, Gilles. A felicidade paradoxal: ensaio sobre a sociedade de hiperconsumo. São Paulo: Companhia das Letras, 2007.

LONGO, Walter. Advertainment e o futuro da propaganda. Disponível em: www.walterlongo.com.br/artigos/Advertainment_e_o_futuro_da_propaganda.html

LUHMANN, Niklas. A realidade dos meios de comunicação. São Paulo: Paulus, 2005.

MARCONDES, Pyr. Uma história da propaganda brasileira: as melhores campanhas, gênios da criação, personagens. Rio de Janeiro: Ediouro, 2002.

MURRAY, Janet; DAHER, Elissa Khoury; CUZZIOL, Marcelo Fernandez. Hamlet no holodeck: o futuro da narrativa no ciberespaço. São Paulo: Itaú Cultural: Unesp, 2003.

PEIRCE, Charles S. Semiótica. São Paulo: Perspectiva, 2000.

PINTO, Julio. 1, 2, 3 da semiótica. Belo Horizonte: UFMG. 1995.

RADFAHRER, Luli. Design/web/design: 2. Market Press, s/d.

SANDMANN, Antônio José. A linguagem da propaganda. São Paulo: Contexto, 2000.

SANT'ANNA, Armando. Propaganda: teoria, técnica e prática. São Paulo: Pioneira, 1998.

SANTOS, Gilmar. Princípios da publicidade. Belo Horizonte: UFMG, 2005. 